\title{
GAMBARAN PEMILIHAN TEMPAT DAN PENOLONG PERSALINAN PADA IBU HAMIL TRIMESTER III DI WILAYAH KERJA PUSKESMAS KARANGNUNGGAL KABUPETEN TASIKMALAYA TAHUN 2012
}

Oleh :

Widya Maya Ningrum, SST., M.Kes

\section{A. Abstrak}

Kematian ibu sebagian besarnya terjadi pada saat persalinan, dimana 9 dari 10 kematian ibu terjadi saat persalinan. Target cakupan pertolongan persalinan oleh tenaga kesehatan adalah sebesar 90\%. Namun, data Riskesdas tahun 2010 mencatat cakupan persalinan oleh tenaga kesehatan terlatih baru mencapai 82,3\%. Puskesmas Karangnunggal Kabupaten Tasikmalaya , cakupan persalinan oleh tenaga kesehatan adalah 68,83 \%. Cakupan ini belum memenuhi target sebesar $80 \%$. Penolong dan tempat persalinan merupakan faktor penentu dalam asuhan persalinan. Keberhasilan proses persalinan yang bersih dan aman sangat dipengaruhi oleh faktor tersebut. Tujuan penelitian ini adalah untuk melihat gambaran pemilihan tempat dan penolong persalinan di Puskesmas karangnunggal tahun 2012.

Jenis penelitian ini termasuk kuantitatif dengan metode deskriptif. Populasi dalam penelitian ini adalah ibu hamil trimester III di wilayah kerja Puskesmas Karangnunggal Kabupaten Tasikmalaya periode April - Juni 2012 sebanyak 43 orang. Variabel dalam penelitian ini yaitu pemilihan tempat dan penolong persalinan.

Hasil penelitian menunjukkan bahwa sebagian besar responden berencana memilih tempat di fasilitas kesehatan yaitu 30 orang $(69,8)$ dan memilih penolong persalinan oleh bidan sebanyak 35 orang (81,4\%). Hal ini menunjukan adanya kesadaran akan pentingnya pemilihan tempat dan peniling persalinan. Meskipun dari hasil tersebut masih ada ibi yang berencana melahirkan di rumah sendiri ataupun di rumah dukun paraji, dan ditolong oelh paraji. Hal ini perlu mendapat perhatian khusus dari tenaga kesehatan wilayah setempat, agar lebih di motivasi untuk memilih tenaga kesehatan dan fasilitas kesehatan dalam proses peralinannya nanti.

Berdasarkan hasil penelitian maka peneliti dapat menarik kesimpulan bahwa sebagian besar ibu hamil pada trimester III memilih tempat persalinan di fasilitas kesehatan dan ditolong oleh bidan. Saran dari hasil penelitian ini adalah Ibu hamil disarankan untuk memeriksakan kehamilan secara rutin ke tenaga kesehatan dan memilih persalinan di fasilitas kesehatandan bagi tenaga kesehatan khususnya bidan Desa diharapkan proaktif dalam membantu ibu hamil dalam mempersiapkan persalinan yaitu dengan cara kunjungan rumah untuk memastikan pilihan tempat dan penolong persalinan .

Kata kunci : Pemilihan tempat dan penolong persalinan 


\section{B. Latar Belakang}

Kematian ibu sebagian besarnya terjadi pada saat persalinan, dimana 9 dari 10 kematian ibu terjadi saat persalinan dan diseputarnya (Depkes RI, 2009). Salah satu faktor yang melatarbelakangi kematian ibu adalah kondisi tiga terlambat, yakni terlambat dalam memeriksakan kehamilan, mengenal tanda bahaya dan mengambil keputusan, terlambat dalam memperoleh pelayanan persalinan dari tenaga kesehatan, dan terlambat sampai di fasilitas kesehatan pada saat dalam keadaan emergensi (Kemenkes RI, 2011).

Saat ini angka kematian ibu (AKI) di Indonesia merupakan angka tertinggi di kawasan Asia Tenggara. AKI di provinsi Jawa Barat sendiri mencapai 724 kasus pada tahun 2008. Untuk kasus kematian bayi, pada tahun 2008 ditemukan sebanyak 41 kasus di Jawa Barat dari 165 kasus di seluruh Indonesia, dimana $60,98 \%$ persalinannya ditangani oleh dukun bersalin (Depkes RI, 2009).

Target cakupan pertolongan persalinan oleh tenaga kesehatan dalam rangka mencapai Indonesia Sehat 2010 adalah sebesar 90\% (Depkes RI, 2003). Namun, data dari Riset Kesehatan Dasar (Riskesdas) tahun 2010 mencatat cakupan persalinan oleh tenaga kesehatan terlatih baru mencapai $82,3 \%$ (Depkes RI, 2010). Dari data Riskesdas tersebut, sebanyak 43,2 \% ibu hamil

\section{Metode}

Jenis penelitian ini termasuk kuantitatif dengan metode deskriptif yaitu suatu metode penelitian yang dilakukan dengan tujuan utama untuk mengetahui gambaran pemilihan tempat dan penolong persalinan pada ibu hamil trimester III di Wilayah Kerja Puskesmas Karangnunggal Kabupaten Tasikmalaya tahun 2012.

Populasi dalam penelitian ini adalah ibu hamil trimester III di wilayah kerja Puskesmas Karangnunggal Kabupaten melahirkan di rumahnya sendiri, dimana hanya $2,1 \%$ yang mendapat pertolongan oleh dokter, 5,9 \% oleh bidan dan 1,4\% oleh tenaga medis lainnya, sisanya sebesar $4 \%$ ditolong keluarga dan yang paling banyak 40,2 \% ditolong dukun beranak (Pramudiarja, 2011). Berdasarkan data Riskesdas tahun 2010, persalinan bukan di fasilitas kesehatan di Jawa Barat mencapai 41,5\%, dan persalinan oleh dukun mencapai 21,5\% (Depkes RI，2010). Berdasarkan data Riskesdas tersebut, berarti cakupan penolong persalinan oleh tenaga kesehatan terlatih secara nasional belum memenuhi target.

Berdasarkan data laporan PWS-KIA (Pemantauan Wilayah Setempat Kesehatan Ibu dan Anak) Puskesmas Karangnunggal Kabupaten Tasikmalaya , cakupan persalinan oleh tenaga kesehatan sampai bulan Desember 2011 adalah $68,83 \%$. Cakupan ini belum memenuhi target dimana untuk bulan April hingga Desember 2011 target persalinan nakes adalah $80 \%$. Disini masih terdapat kekurangan sebesar 11,17\%. Menurut Depkes RI (2009), tujuan persiapan persalinan aman adalah agar ibu hamil dan keluarga tergerak merencanakan tempat dan penolong persalinan yang aman, yang mana menurut Kemenkes RI (2011) persalinan dilakukan di fasilitas kesehatan dan ditolong oleh tenaga kesehatan.

Tasikmalaya periode April - Juni 2012 dan teknik pengambilan sampel menggunakan teknik total sampling yaitu seluruh populasi dijadikan sampel dalam penelitian ini yiatu sebanyak 43 orang.

Prosedur pengumpulan data pada penelitian ini berupa data primer yaitu pengumpulan data secara langsung dari responden menggunakan kuesioner mengungkap persiapan persalinan oleh ibu hamil. Kuesioner tersebut diberikan kepada ibu hamil melalui kunjungan 
rumah yang dibantu oleh kader kesehatan yang ada di tiap desa.

Data yang telah ada diolah dan dianalisis dengan melalui tahap :

a. Editing Data, yaitu pemeriksaan kuesioner, apakah masih ada yang kurang lengkap atau ada jawaban atau data yang kurang konsisten

b. Coding Data, yaitu melakukan pengkodean data agar tidak terjadi kekeliruan dalam melakukan tabulasi data.

c. Tabulating Data, yaitu melakukan pengolahan data berdasarkan hasil kuesioner.

\section{Hasil Penelitian}

Karakteristik Responden

1. Umur

Karakteristik

responden

berdasarkan umur di wilayah kerja

Puskesmas Karangnunggal Kabupaten

Tasikmalaya tahun 2012.

\begin{tabular}{|c|c|c|}
\hline $\begin{array}{c}\text { Usia } \\
\text { (tahun) }\end{array}$ & Jumlah & $\%$ \\
\hline$<20$ & 2 & 4,7 \\
\hline
\end{tabular}

Berdasarkan tabel 5.1 dapat diketahui bahwa karakteristk responden berdasarkan umur paling banyak berusia 20-35 tahun yaitu 30 orang $(69,8 \%)$, umur $>35$ tahun sebanyak 11 orang $(25,6 \%)$ dan berumur $<20$ tahun sebanyak 2 orang $(4,7 \%)$.

2. Pekerjaan

Karakteristik responden berdasarkan pekerjaan di wilayah kerja Puskesmas Karangnunggal Kabupaten Tasikmalaya tahun 2012.

\begin{tabular}{|l|c|c|}
\hline \multicolumn{1}{|c|}{ Pekerjaan } & Jumlah & $\%$ \\
\hline PNS & 2 & 4,7 \\
\hline Pegawai swasta & 3 & 7,0 \\
\hline Petani & 3 & 7,0 \\
\hline Buruh & 11 & 25,6 \\
\hline IRT & 24 & 55,8 \\
\hline
\end{tabular}

Tabel 5.2 diatas menunjukkan paling banyak pekerjaan responden adalah sebagai IRT yaitu 24 orang d. Entry Data, yaitu memasukan data ke dalam komputer.

Analisis data yang digunakan adalalah analisis univariat untuk menganalisis variabel persiapan persalinan melalui distribusi frekuensi menggunakan rumus :

$$
P=\left(\frac{F}{N}\right) x 100 \%
$$

Ket $: \mathrm{P}=$ Presentase

$\mathrm{F}=$ Jumlah responden sesuai kategori

$\mathrm{N}=$ Jumlah seluruh sampel

$(55,8 \%)$ dan paling sedikit sebagai PNS yaitu 2 orang $(4,7 \%)$.

3. Frekuensi hamil

Karakteristik

responden

berdasarkan frekuensi kehamilan di

wilayah kerja Puskesmas

Karangnunggal Kabupaten

Tasikmalaya tahun 2012

\begin{tabular}{|l|c|c|}
\hline \multicolumn{1}{|c|}{ Kehamilan } & Jumlah & $\%$ \\
\hline Primigravida & 11 & 25,6 \\
\hline Multigravida & 31 & 72,1 \\
\hline Grandemultigravida & 1 & 2,3 \\
\hline Total & 43 & 100 \\
\hline
\end{tabular}

Tabel 5.3 diatas menunjukkan bahwa sebagian besar responden dengan kehamilan multigravida 31 orang $(72,1 \%)$ dan sebagian kecil yang grandemultigravida 2,3\%

4. Tempat Persalinan

Distribusi frekuensi pemilihan tempat persalinan di wilayah kerja Puskesmas Karangnunggal Kabupaten Tasikmalaya tahun 2012.

\begin{tabular}{|l|c|c|}
\hline \multicolumn{1}{|c|}{$\begin{array}{c}\text { Tempat } \\
\text { persalinan }\end{array}$} & Jumlah & $\%$ \\
\hline $\begin{array}{l}\text { Rumah dukun } \\
\text { paraji }\end{array}$ & 2 & 4,7 \\
\hline Rumah sendiri & 11 & 25,6 \\
\hline $\begin{array}{l}\text { Fasilitas } \\
\text { kesehatan }\end{array}$ & 30 & 69,8 \\
\hline Total & 43 & 100 \\
\hline
\end{tabular}


Tabel 5.4 diatas menunjukkan bahwa sebagian besar responden berencana memilih tempat di fasilitas kesehatan yaitu 30 orang $(69,8 \%)$, memilih di rumah sendiri yaitu 11 orang $(25,6 \%)$ dan memilih di rumah dukun paraji yaitu 2 orang $(4,7 \%)$.

5. Penolong Persalinan

Distribusi frekuensi pemilihan penolong persalinan di wilayah kerja Puskesmas Karangnunggal Kabupaten Tasikmalaya tahun 2012

\section{E. Pembahasan}

Hasil penelitian melalui kuesioner mengenai pemilihan penolong dan tempat persalinan penulis menemukan beberapa pernyataan dari responden yang mengarah pada program dari Depkes RI yaitu program perencanaan persalinan dan pencegahan komplikasi (P4K). Program ini akan mendata identitas ibu hamil dan beberapa persiapan dalam menghadapi persalinan. Kesiapan itu salah satunya meliputi, tempat persalinan, siapa yang melakukan pertolongan persalinan, dan itu harus tercatat pada stiker yang terpampang di rumah setiap ibu hamil (Depkes RI, 2005).

Persiapan tempat persalinan berdasarkan hasil penelitian melalui kuesioner menunjukkan bahwa sebagian besar responden berencana memilih tempat di fasilitas kesehatan yaitu 30 orang $(69,8 \%)$, memilih di rumah sendiri yaitu 11 orang $(25,6 \%)$ dan memilih di rumah dukun paraji yaitu 2 orang $(4,7 \%)$. Pemilihan tempat persalinan ini responden mengaku menyesuaikan dengan keterjangkauan baik ekonomi maupun jarak tempuh. Menurut Wardoyo (2007) tempat melahirkan hendaknya disesuaikan dengan jarak tempuh dari rumah untuk memperkirakan waktu sampai ke tempat, prosedur masuk, fasilitas yang ada, biaya persalinan, Lokasi kamar

\begin{tabular}{|l|c|c|}
\hline Penolong & Jumlah & $\%$ \\
\hline Dokter & 2 & 47,7 \\
\hline Bidan & 35 & 81,4 \\
\hline Dukun & 6 & 14,0 \\
\hline Total & 43 & \\
\hline
\end{tabular}

Tabel 5.5 diatas menunjukkan bahwa ibu hamil yang memilih penolong persalinan oleh bidan sebanyak 35 orang $(81,4 \%)$, memilih dukun paraji sebanyak 6 orang $(14,0 \%)$ dan memilih dokter sebanyak 2 orang $(4,7 \%)$.

bersalin, agar dalam keadaan darurat mempercepat sampai ke tempat tujuan.

Sebagaimana yang diketahui bahwa persiapan persalinan merupakan salah satu program yang terdapat dalam Desa Siaga. Keberadaan Desa di wilayah kerja Puskesmas Karangnunggal telah terbentuk desa siaga sehingga dengan terbentuknya desa siaga ini dapat menunjang terhadap pemilihan tempat persalinan. Begitupun dengan program jaminan persalinan dimana sejak tahun 2011 program tersebut telah dterapkan oleh pemerintah dengan sasarannya adalah ibu hamil, ibu nifas, bayi baru lahir dan ibu menyusui.Walaupun program Jampersal telah dilaksanakan di wilayah kerja Puskesmas Karangnunggal, namun hasil penelitian mengenai pemilihan tempat persalinan masih terdapat ibu hamil yang memilih di rumah sendiri ataupun rumah dukun paraji.

Hal yang menjadi pertimbangan adalah keterjangkauan ke fasilitas, aspek ekonomi untuk perbekalan selama menunggu persalinan dan aspek kemudahan dalam mengurus surat-surat untuk persyaratan Jampersal.Selain itu, beberapa alasan faktor yang berhubungan pemilihan tempat persalinan di rumah adalah terkait dengan karakteristik responden dimana sebagian besar responden bekerja sebagai IRT $(55,8 \%)$. 
Pekerjaan merupakan indikator dari pendapatan yang diterima oleh ibu dan keluarga perbulan, dengan memiliki pendapatan yang pas-pasan atau bahkan kurang membuat keluarga memilih persalinan di rumah yang lebih murah bila dibandingkan di fasilitas kesehatan. Keterjangkauan harga merupakan suatu hal yang dipikirkan oleh ibu hamil dan keluarga, dengan memiliki ekonomi yang tinggi ibu hamil cenderung akan melakukan persalinan di fasilitas kesehatan. Sehubungan dengan biaya yang relatif, maka hal ini sangat membuktikan bahwa tingkat sosial ekonomi sangat mempengaruhi perilaku ibu hamil dalam memilih tempat persalinan. Menurut responden apabila bersalin di tenaga kesehatan sangat membutuhkan biaya yang cukup besar di bandingkan dengan bersalin di rumah. Selain sangat menghemat biaya bersalin di bukan tenaga kesehatan juga sangat di dukung oleh keluarga dan suami sehingga responden lebih memilih bersalin di bukan tanaga kesehatan.Hal ini sesuai dengan Lesti (2007) yang mengatakan bahwa persalinan di rumah ada kelebihan dan kekurangannya. Kelebihannya, suasana di rumah yang akrab membuat ibu hamil merasa didukung keluarga maupun tetangga.

Kamar selalu tersedia dan tak memerlukan pengangkutan ke rumah sakit. Di rumah, ibu hamil terhindar dari infeksi silang yang $b$ isa terjadi di rumah sakit. Hal terpenting, biaya bersalin di rumah jauh lebih murah. Namun disisi lain persalinan dirumah mempunyai kekurangan yaitu penolong persalinan cenderung dilakukan oleh dukun bayi, bidan atau tenaga lain) umumnya hanya satu. Sanit asi, fasilitas, peralatan dan persediaan air bersih mungkin kurang, sehingga apabila terjadi kegawat daruratan diperlukan pengangkutan dan pertolongan pertama selama perjalanan, bahkan apabila mengalami komplikasi yang terjadi misalnya perdarahan atau kejang-kejang dapat lebih parah.
Berbeda dengan responden yang memilih tempat persalinan di fasilitas kesehatan, dimana bersalin di tempat fasilitas kesehatan sebanyak $69.8 \%$. data ini menunjukkan bahwa bersalin di fasilitas kesehatan memiliki fasilitas untuk perawatan bayi/anak jika memerlukan perawatan lebih lanjut, jika terjadi gangguan setelah proses persalinan. Disebut rumah sakit ibu dan anak karena bukan hanya untuk ibu hamil dan melahirkan, tetapi juga wanita yang memerlukan pengobatan untuk penyakit kandunganFasilitas kesehatan tersebut dapat berupa rumah bersalin,rumah sakit, rumah bersalin atau Puskesmas. Pemilihan tempat persalinan didasarkan atas informasi dari tenaga kesehatan sehingga memiliki keuntungan bagi ibu dan keluarga, dapat memudahkan perhitungan antara kebutuhan, kenyamanan, dan keinginan, serta tentu saja kemampuan keuangan yang dimiliki.

Hasil penelitian mengenai persiapan penolong persalinan diperoleh data bahwa ibu hamil yang memilih penolongpesalinan oleh bidan sebanyak 35 orang $(81,4 \%)$, memilih dukun paraji sebanyak 6 orang $(14,0 \%)$ dan memilih dokter sebanyak 2 orang $(4,7 \%)$. Hal ini dikarenakan responden menganggap bahwa bidan dapat memberikan pelayanan yang lebih baik dengan tidak memperhitungkan dan memberatkan salah satunya dalam segi biaya dan harganya pun tidak jauh dari paraji. Berdasarkan pernyataan tersebut dapat dikemukakan bahwa sebagian besar responden sudah mempersiapkan penolong persalinan oleh tenaga kesehatan yang terampil dan profesional, artinya responden dapat mengetahui penolong persalinan yang bersih dan aman. Pemilihan penolong persalinan ini dimungkinkan karena sebagian besar responden telah percaya kepada tenaga kesehatan hal ini terbukti dengan persalinan di paraji sedikit di pilih responden di bandingkan persalinan di 
bidan.Menurut Purwaganda (2008) bahwa kematian ibu di Indonesia sebagian besar disebabkan oleh komplikasi kelahiran berupa perdarahan, infeksi dan eklampsia. Penyebab kematian ini dapat diatasi dengan perenanaan yang baik sejak kehamilan dan bahwa cara efektif untuk menurunkan AKI dan AKB adalah dengan mengupayakan semua persalinan dengan bantuan tenaga kesehatan, artinya bahwa persalinan dengan bantuan paraji sebisa mungkin dihindarkan.

Pemilihan penolong persalinan responden dengan memilih ke tenaga kesehatan (bidan dan dokter) artinya responden menyadari dan dapat menerima / memahami pelayanan pertolongan persalinan yang adekuat, bersih dan aman. Hal lain yang mendorong responden melakukan pertolongan pemilihan persalinan di tenaga kesehatan adalah ekonomi dan pendidikan.Hal ini sesuai dengan yang dikemukan oleh Azrul (2002) menyatakan bahwa ekonomi selalu menjadi faktor penentu dalam proses kehamilan dan persalinan yang sehat. Keluarga dengan ekonomi cukup memeriksakan kehamilan secara rutin, merencanakan persalinan di tenaga kesehatan dan melakukan persiapan lainnya dengan baik. Dengan adanya perencanaan dengan baik sejak awal, maka kehamilan dan proses persalinan dapat berjalan dengan baik. Artinya responden dengan ekonomi sedang lebih memilih persalinan di bidan agar proses persalinan dapat berjalan dengan baik dengan biaya persalinan cukup terjangkau.

Namun data lain menunjukkan terdapat responden yang memilih penolong persalinan oleh dukun paraji yaitu 6 orang $(4,7 \%)$, hal ini dikaitkan dengan kebiasaan yang turun temurun, walaupun dalam hal ini penulis tidak meneliti masalah sosial budaya namun perlu dikemukakan bahwa budaya tersebut masih kental dimasyarakat. Kebiasaan yang ada di lapangan menunjukkan bahwa ibu bersalin dan keluarga mengikutsertakan dukun paraji dalam ritual keagamaan misalnya dalam acara 4 dan 7 bulan kehamilan. Suami atau keluarga ibu menganjurkan untuk memeriksakan kehamilan ke dukun paraji,di dalam keluarga ada suatu keharusan untuk melahirkan oleh dukun paraji, keyakinan masyarakat bahwa dukun paraji berpengalaman menolong persalinan dan merasa yakin dukun paraji lebih menentramkan jiwa, misalnya dengan do'a-do'a atau jampijampi.Hasil penelitian tersebut sesuai dengan teori dari Swasono (2008) yang mengatakan bahwa dalam pemilihan pertolongan persalinan, peranan sosial budaya sangat penting, karena keputusan yang turun temurun ini akan terus dilanjutkan oleh keturunannya.

Di pedesaan lingkungan sosial budaya mempunyai pengaruh yang kuat terhadap perilaku seseorang, dan peranan kelompok referensi di masyarakat sangat dirasakan. Kuatnya tradisi di masyarakat pedesaan menyebabkan mereka tidak berani meninggalkan tradisi, naluri khususnya yang berkaitan dengan persalinan.Beberapa hal yang menjadi alasan ibu bersalin di tenaga kesehatan, penulis berpendapat bahwa karakteristik berpengaruh terhadap pemilihan penolong persalinan. Walaupun dalam hal ini peneliti tidak mengkaji tentang hubungan karakteristik dengan persiapan persalinan, namun peniliti berpendapat bahwa masyarakat berpendidikan tinggi akan responden dan berperilaku sehat, dalam hal ini masyarakat berpendidikan tinggi akan mencari pertolongan persalinan yang bersih dan aman sesuai dengan pengetahuannya yang dimilikinya. 


\section{F. Simpulan dan saran}

Berdasarkan hasil penelitian maka peneliti dapat menarik kesimpulan bahwa sebagian besar ibu hamil pada trimester III memilih tempat persalinan di fasilitas kesehatan dan ditolong oleh bidan.

Saran :

1. Bagi Ibu Hamil

Ibu hamil disarankan untuk memeriksakan kehamilan secara rutin ke tenaga kesehatan dan memilih persalinan di fasilitas kesehatan

2. 2. Bagi Bidan /Khususnya Bidan Desa

Bidan diharapkan proaktif dalam membantu ibu hamil dalam mempersiapkan persalinan yaitu dengan cara kunjungan rumah untuk memastikan pilihan tempat dan penolong persalinan .

3. Keluarga

Keluarga disarankan untuk mempersiapkan persalinan sejak awal dari mulai ibu dinyatakan hamil, melakukan pemeriksaan kehamilan agar dapat memperoleh informasi mengenai rencana tempat dan penolong persalinan, hal yang harus dipersiapkan menjelang persalinan serta biaya yang harus disediakan sehingga persalinan ibu dapat berjalan dengan lancar atau sesuai dengan rencana.

\section{G. Referensi}

Ahira, 2009. Persiapan Sebelum Kehamilan.

http://www.bidanku.com

Arnesih, 2007. Persiapan Mental Calon Orang Tua. http://www.ayahbunda-online.com

Depkes RI. 2009. Persiapan Persalinan.

http://litbang.kemenkes.go.id
Indrawati, 2010. Panduan Perawatan

Kehamilan. Jogjakarta. Atma Media Press

Jumirah dkk, 2012. peran masyarakat dan keluarga dalam pengambilan keputusan persalinan. http://www.ayahbunda.online.com

Jembawan. Pengambilan Keputusan Dalam Perspektif Gender. http://infobidam.com

Matterson, 2001: Jurnal : Persiapan Ibu Menghadapi Persalinan. http://mediacastore.com

Muria, 2008. Persiapan Kehamilan Dan Persalinan. (diunduh 28 Februari 2011) Tersedia dari: http://www.bisnisbali.com

Musyaddad, 2003. Pengambilan Keputusan Dalam Pertolongan Persalinan Di Provinsi Nusa Tenggara Timur.

Notoatmodjo. 2007. Kesehatan Masyarakat: Teori dan Aplikasi. Rhineka Cipta. Jakarta

Prahasta, 2011. Menumbuhkan Kesadaran Kesehatan Reproduksi Persiapan Kehamilan dan Melahirkan. http://digilib.unikom.ac.id

Saifuddin, 2008. Ilmu Kebidanan. Jakarta. Yayasan Bina Pustaka Sarwono Prawirohardjo

SDKI, 2007. Survey Demografi Kesehatan Indonesia : Angka Kematian Ibu dan Bayi. http://www.bascomword.com

Triexs Media, 2009. 1001 Tentang Kehamilan. Prefect Edition. Triex Media. Bandung

Wiknjosasatro, 2007. Buku Acuan Nasional Pelayanan Kesehatan Maternal dan Neonatal. Jakarta. Yayasan Bina Pustaka Sarwono Prawirohardjo. 